\title{
What are and Why Study Later Medieval Theories of Animal Rationality?
}

Contemporary theories of animal rationality concern a relatively wide range of issues. They range from inferential and linguistic capacities to social and meta-cognition. ${ }^{1}$ What is common to most of them is that they are interested in process rather than behavioural rationality. ${ }^{2}$ Generally speaking, these are different ways of telling whether or not a being is rational. When we focus solely on its behaviour and say that it is rational, since, for instance, it chooses the right means to achieve a certain end (and so 'maximises utility', as some people put it) we ascribe behavioural rationality to that being. According to this concept of rationality, almost any kind of being could count as rational in one way or another. Not only people can be rational but also institutions, machines, or genes as long as they behave in a way that qualifies as rational. ${ }^{3}$ What matters is simply whether or not a certain behaviour can be described as rational. If this is the case, then the being exhibiting this behaviour can be called rational.

However, this type of rationality is much more interesting and relevant for economists, for example, than it is for psychologists. The latter are interested rather in the question whether the behaviour we observe is based on rational processes. To put it slightly differently, they wonder how a certain kind of behaviour is brought about. For instance, they examine whether a certain kind of behaviour that can be described as rational from the outside is actually based on a rational cognitive process such as reasoning. To be clear, this does not mean that psychologists or anyone else interested in process rationality work with a better or more appropriate concept of rationality than economists and people interested in behavioural rationality. They simply look at rationality from a different angle, and when they identify rationality they do this at a different level.

In the Middle Ages, one can also find this distinction between behavioural and process rationality - not literally, of course, but systematically. A passage that neatly illustrates this is found in Thomas Aquinas' Summa theologiae.

\footnotetext{
1 The most comprehensive and insightful volume on these theories is Hurley \& Nudds (2006a). See also Perler \& Wild (2005) and Lurz (2009).

2 See Hurley \& Nudds (2006b), 5 f.

3 See Kacelnik (2006), 90-93.
} 
When we look at how things behave, Aquinas says, we might get the impression that not only humans but also artefacts, such as arrows or clocks, are rational. An arrow, for instance, seems to behave rationally by moving directly towards its target. ${ }^{4}$ Taking up the above-mentioned terminology one could say that the arrow shows behavioural rationality. It chooses the right means for achieving a certain end. However, Aquinas stresses that this is somehow beside the point, because what really matters when we try to identify whether or not something is rational are the following two criteria. First, we need to ask whether a certain behaviour is based on a rational process. Thus, like contemporary psychologists Aquinas looks for process rationality. In this sense, an arrow is not a rational being because its moving towards the target is not based on a rational process. ${ }^{5}$ The arrow does not reason that it needs to fly in this or that direction in order to hit the target. Rather, it is the shooter that engages in this sort of cognitive operation. Yet, one might ask why Aquinas (and other medieval authors) think the shooter is capable of doing this. How is it that the shooter can engage in a process such as reasoning, while the arrow cannot?

The answer, in short, is that the shooter is endowed with certain rational faculties, namely, intellect and reason. This is the second thing one needs to take into account when talking about rationality, according to Aquinas. What lies behind this point is the Aristotelian theory of the soul. According to this theory, one can only engage in a certain process if one is endowed with a particular power or faculty. For things like digestion or growth one needs vegetative powers, sensing requires sensory powers, and rational cognition demands rational powers. ${ }^{6}$ So besides behavioural and process rationality there seems to be a third type of rationality for medieval Aristotelians and this could be called faculty rationality. Very likely, it is because of this concept of rationality that Aristotle and his medieval followers have such a bad reputation these days when it comes to the question of animal rationality because it establishes

4 Thomas Aquinas, Summa theologiae I-II, q. 13, a. 2, ad 3, ed. Leonina VI (1891), 99: “[...] in omnibus quae moventur a ratione, apparet ordo rationis moventis, licet ipsa rationem non habeant: sic enim sagitta directe tendit ad signum ex motione sagittantis, ac si ipsa rationem haberet dirigentem. Et idem apparet in motibus horologiorum, et omnium ingeniorum humanorum, quae arte fiunt." For a more detailed analysis of this passage see Chapter 19.

5 It is not even minimally rational in the sense in which Dretske (2006), 107, defines it because, in his view, " $[\mathrm{m}]$ inimal rationality requires that thought be involved in the process by means of which the behaviour is produced." The arrow's movement is, however, not based on any kind of thought or mental representation.

6 On Aristotelian faculty psychology see the articles in Perler (2015a). On its medieval Latin reception in particular see King (2008) and Perler (2015b). 
what is usually called a very strong 'anthropological difference'. This means that it clearly defines "features of homo sapiens that (a) set us apart 'categorically' or 'essentially' from all other animals; (b) are fundamental, in that (all) other relevant differences derive from them; (c) are important, notably to our self-image, for instance because they assure us of a higher spiritual or moral status than animals," as Hans-Johann Glock summarises the key features of an anthropological difference. ${ }^{7}$

For Aristotelians in general and later medieval Aristotelians in particular, reason does exactly this kind of job: (a) It establishes a metaphysical difference between humans and other animals because only humans are endowed with immaterial rational souls. (b) It establishes a cognitive difference because only these souls are endowed with what could be called the 'triad of intellectual operations', including concept formation, judging, and reasoning (see Chapter 6). (c) It establishes a moral difference because only rational beings can act for reasons, hence be morally responsible for what they do. Moreover, only such beings can be redeemed from sin, not at least because only their immaterial souls survive the death of the body. In sum, medieval Aristotelians defend a version of rationalism in the sense that for them reason is what marks the decisive difference between humans and other animals - metaphysically, cognitively, and morally. ${ }^{8}$ Therefore, it seems that there exists nothing like a medieval version of theories of animal rationality because rationality is exactly what sets humans apart from nonhuman animals.

As mentioned before, this conclusion fails to capture the depth and diversity of the medieval discussion. Most importantly, it ignores the fact that later medieval thinkers were well aware of what can be called the 'grey areas' of Aristotelian faculty psychology (see Chapter 7 ). ${ }^{9}$ These areas become obvious in those cases in which an animal that is non-rational by definition shows a certain behaviour that, when seen in a rational being, is explained by its rationality. A classical example that illustrates such a case is the example of 'Chrysippus' dog' (it is this example, by the way, that Aquinas discusses in the

7 Glock (2012), 109. See also Glock (2016b), 17.

8 On this concept of rationalism see Wild (2006), 5 f. Note, however, that defenders of this kind of rationalism usually put much emphasis on the capacity of language. In the medieval period, this relation exists as well but is less prominent in the discussion of animal rationality, as we shall see.

9 I adopt this term from Jones (2013), 63, who, in his concise chapter on man and nature in the Middle Ages, remarks that "[i]f rationality could be used as a defining marker of humanity there remained a number of grey areas." In particular, he has in mind the (apparently) rational behaviours of human infants and nonhuman animals. 
passage mentioned above). ${ }^{10} \mathrm{~A}$ dog chases a deer but suddenly loses sight of it. It comes to a fork with three paths and sniffs around the first and the second path. It then takes the third path but without having sniffed around it. The question is how to explain the dog's behaviour. In the case of a human being, the explanation would go like this: the decision to take the third path arises from a rational operation such as 'The deer must have taken path $\mathrm{A}, \mathrm{B}$, or $\mathrm{C}$. If there is no trace of it at path A and B, then it must have taken C. To put it in logical terms, the human being employs a disjunctive syllogism and this is what causes its behaviour. But what about the behaviour of the dog? How can one explain that the dog shows the same behaviour as a human being in this situation?

One possible answer is that the dog's behaviour derives from the same kind of cognitive process as the corresponding human behaviour. If this human behaviour is explained by a process such as reasoning the dog's behaviour should be explained by reasoning as well. The argument behind this answer is commonly known as the 'argument from analogy'.11 In short, the argument goes like this: If we observe the same effects, that is, the same behaviours in two different animals we must assume that these effects are brought about by the same causes, that is, the same cognitive processes. So when we see a dog solve a certain problem that humans normally solve by reasoning we must assume that the dog solves it by reasoning, too. Two prominent defenders of this argument in the history of Western philosophy are Michel de Montaigne and David Hume. Both agreed that from like (behavioural) effects one should infer like (cognitive) causes, even across species. ${ }^{12}$ Therefore, it is hardly surprising that they made a strong case for the rationality of nonhuman animals.

This kind of argument, however, seems to be unavailable to medieval thinkers because it is incompatible with the Aristotelian model of the soul. To argue that both humans and dogs solve problems by reasoning runs counter to the idea that a process such as reasoning requires a rational faculty, the possession of which is exactly what separates humans from dogs. Surprisingly, though, later medieval thinkers show much more flexibility than one is usually inclined to expect. Instead of discarding the argument from analogy right away, they employed different explanatory strategies to deal with the problem of grey areas

10 On the origin, history, and reception of this example, see Floridi (1997). A recent philosophical analysis and discussion is provided by Rescorla (2009). On Aquinas's discussion see Chapter 19.

11 See Wild (2013), 84-89.

12 Although both Montaigne and Hume defend the argument from analogy the ways in which they spell it out differ slightly; see Wild (2006), 248. 
in Aristotelian psychology (see Chapter 32). Some (e.g. Thomas Aquinas and John Duns Scotus) chose what is called the strategy of 'differentialism' in modern animal philosophy. That is to say, they tried to maintain the anthropological difference that is established by the Aristotelian model of the soul. In those cases where this model came under attack, for instance, in virtue of the similarities in the behaviours of human and nonhuman animals, they searched for explanations that avoid the argument from analogy and trace similar behaviours back to different cognitive causes. Even though the behaviour of Chrysippus' dog looks rational from the outside and so might qualify as behaviourally rational it is not rational from the inside, that is, neither with regard to the faculties nor with regard to the processes that bring it about.

Still, this kind of explanation was not accepted by everyone. As will become clear, there are several cases in which later medieval authors chose the strategy that is now generally called the strategy of 'assimilationism'. Instead of maintaining, if not even deepening the anthropological difference, they somehow assimilated humans and other animals. To be clear, this does not mean that they abandoned the basic principles of Aristotelian faculty psychology. Most importantly, they did not reject the denial of rational faculties to nonhuman animals. Nevertheless, some of them considered the option of what might be called 'rationality without reason' (see Chapter 33). This means that they in some sense dissolved the link between process and faculty rationality. They held that at least some nonhuman animal species can engage in rational processes, such as reasoning, although they lack rational faculties. How this is actually possible was the matter of some debate, but there were different solutions available. Albertus Magnus, for instance, argued that certain inner senses of some highly-developed nonhuman animals can engage in simple forms of reasoning (see Chapter 21). ${ }^{13}$ He thus upgraded the powers of the sensory soul. Nevertheless, he tried to maintain the metaphysical difference between nonhuman animals' material sensory souls and the immaterial rational souls of humans. John Buridan went even further by claiming that this metaphysical difference does not exist (see Chapter 22). In his opinion (which was inspired by Alexander of Aphrodisias), all souls are material forms. He did not deny that human cognition is superior to nonhuman animal cognition in various respects but cognitive performance depends on material complexity. Hence, those animals whose souls are (almost) as complex as those of humans can engage in similar cognitive operations. ${ }^{14}$

13 On this see, for instance, Roling (2011), esp. 229-233; Köhler (2014), esp. 388; Tellkamp (2016).

14 See Pluta (1996), 92-97, and (2015), esp. 281-286. 
What this variety of explanations shows is that later medieval authors did not necessarily select "just one side from a much more wide-ranging Greek debate," as claimed by scholars like Sorabji. ${ }^{15}$ Indeed, the medieval Latin discussion differs from the ancient Greek debate in various respects. One of the main reasons for the differences is that many of the materials that covered different parts of the spectrum of the Greek discussion were not available to Latin medieval authors. Still, there was a vivid debate about whether or not nonhuman animals can be rational in the Middle Ages, too, and from this debate arose various theories of animal rationality.

The landscape of those theories has not yet been mapped and it is the aim of this book to provide such a map. It will do this by combining primary sources from roughly $125^{0}$ to $135^{\circ}$ (see Chapter 2 below) and secondary literature, both systematical and historical. As far as the latter is concerned, several studies that have been published in current scholarship provide an excellent starting point. They include works on medieval anthropology and animal cognition covering a wider range of views ${ }^{16}$ as well as studies on the positions of particular authors, from Albertus Magnus, ${ }^{17}$ Roger Bacon, ${ }^{18}$ and Thomas Aquinas ${ }^{19}$ to Peter of John Olivi ${ }^{20}$ and John Buridan. ${ }^{21}$ This list might actually create the impression that the aforementioned gap in the scholarship does not exist. And, indeed, the growing cross-disciplinary interest in animals has generated increasing interest not only in ancient ${ }^{22}$ and early modern positions ${ }^{23}$ but also

\footnotetext{
15 See p. 2 n4.

16 Among the most substantial and comprehensive studies on medieval anthropology are Köhler (2008) and (2014). Köhler (2000) also forms part of this impressive project. On animal cognition in the late ancient and early medieval period see Nitschke (1967); Clark (1998); Matthews (1999); Brittain (2002). Later centuries are covered by Sobol (1993); Perler (2006), (2012b); Roling (2011), (2013a), (2013b). General overviews of animals in medieval philosophy provide De Leemans \& Klemm (2007); Jones (2013), esp. 62-72; Toivanen (forthcoming).

17 See, for instance, Balss (1954); Hünemörder (1980); Resnick \& Kitchell (1996); Guldentops (1999) and (2000); Köhler (2001); Anzulewicz (2009); Tellkamp (2013) and (2016).

18 Wood (2007) and Hackett (2013).

19 The most recent monograph on Aquinas is Davids (2017) who substantially revises Barad (1995). Articles on Aquinas include Deeley (1971); Hünemörder (1988); Manzanedo (1989) and (1990); Yamamoto (1998); Loughlin (2001); Juanola (2015).

20 Toivanen (2011) and (2013a).

21 Zupko (2008); Pluta (2015).

22 See p. 2 ns.

23 The prime example is undoubtedly Wild (2006) who covers Montaigne, Descartes, and Hume. Studies or volumes with a broader range include Fudge (2006); Muratori (2013); Muratori \& Dohm (2013); Roling (2014); Meo-Ehlert (2015); Buchenau \& Lo Presti (2017).
} 
in medieval ones. Nonetheless, there is no single monographic study which provides a historical reconstruction as well as a systematic discussion of medieval theories with a particular focus on rationality. Such a study can aid those interested in the history of philosophy as well as provide interesting insights for anyone engaged in the present debate, because by looking at the theories from the medieval period we might see more clearly what characterises the theories of our own age. 